\title{
Sistem Prediksi Kebutuhan Obat di Puskesmas Menggunakan Metode Least Square
}

\author{
Devit Suwardiyanto ${ }^{1 *}$, Mohammad Nur Shodiq ${ }^{2}$, Dedy Hidayat Kusuma ${ }^{3}$, Tovia Oktalita Sari ${ }^{4}$ \\ 1,2,3,4 Jurusan Teknik Informatika, Politeknik Negeri Banyuwangi, Banyuwangi \\ 1,2,3,4Jln. Raya Jember KM13, Labanasem, Kabat, Banyuwangi, 68461, Indonesia \\ email: ${ }^{1}$ ds@ poliwangi.ac.id, ${ }^{2}$ noer.shodiq@ poliwangi.ac.id, ${ }^{3}$ dedy@ poliwangi.ac.id, ${ }^{4}$ toviaokta.ti8.poliwangi@gmail.com
}

\author{
Copyright $@ 2019$, Politeknik Harapan Bersama, Tegal
}

\begin{abstract}
The Puskesmas is a health service center at the first level in the community. Medication is an important requirement in health agencies, including health centers. The Puskesmas must provide medicine for patients for a period of a month. As well, the puskesmas also has to plan drug requests for the period of the following month. The problem that often arises is about drug supplies. If the demand for drugs is too much, it will cause the drug to be removed for a long period of time, so that it will result in drug expiration. Likewise, if the demand for drugs is too little then it becomes less good, which results in less optimal service to the community. During this time, planning for drug demand for use in the next period, still using instinctive techniques by the head of the health center of the puskesmas. So, this will lead to excess or even reduced drug supply. In this study a system that is able to predict future drug needs was built. The results of this prediction can be used as a reference for drug requests to the health department. The method used to predict is the Least Square method, while the system to control the upper and lower limits uses the Minimum Maximum Stock Level (MMSL) method. The test system for prediction errors in this study uses Mean Absolute Percentage Error (MAPE). This systems was implemented using the PHP language and visualized on a web-based basis. The system test results showed an average prediction error rate of $12.70 \%$. The existence of this system is expected to be able to assist the planning process of drug needs in the future at the puskesmas.
\end{abstract}

Abstrak-Puskesmas merupakan pusat pelayanan kesehatan ditingkat pertama pada masyarakat. Obat merupakan kebutuhan yang penting dalam instansi kesehatan, termasuk puskesmas. Puskesmas harus menyediakan persediaan obat untuk pasien selama jangka waktu satu periode atau bulan. Serta, puskesmas juga harus membuat perencanaan permintaan obat selama satu periode di bulan berikutnya. Permasalahan yang sering muncul adalah tentang persediaan obat. Apabila permintaan obat terlalu banyak akan mengakibatkan obat akan tertumpuk dalam jangka waktu yang lama, sehingga akan mengakibatkan kadaluarsa obat. Begitupula, apabila permintaan obat terlalu sedikit maka menjadi kurang baik, yang mengakibatkan pelayanan kepada masyarakat kurang optimal. Selama ini perencanaan permintaan obat untuk penggunaan di periode selanjutnya, masih menggunakan teknik insting oleh kepala gudang obat puskesmas sehingga hal ini akan mengakibatkan kelebihan atau bahkan bisa berkurangnya

*) Corresponding Author: (Devit Suwardiyanto)

Email: ds@poliwangi.ac.id persediaan obat. Pada penelitian ini dibangun sebuah sistem yang mampu memprediksi kebutuhan obat di masa mendatang. Hasil prediksi ini dapat dijadikan sebagai acuan sebagai permintaan obat ke dinas kesehatan. Metode yang digunakan untuk memprediksi adalah metode Least Square.

Sedangkan sistem untuk mengontrol batas atas dan bawah menggunakan metode Minimum Maximum Stock Level (MMSL). Sistem pengujian terhadap kesalahan prediksi dalam penelitian ini menggunakan Mean Absolute Percentage Error (MAPE). semua sistem ini diimplementasikan menggunakan bahasa $P H P$ dan divisualisasikan berbasis web. Hasil pengujian sistem diperoleh rata-rata tingkat error prediksi sebesar $12,70 \%$. Dengan adanya sistem ini diharapkan dapat membantu proses perencanaan kebutuhan obat dimasa mendatang di puskesmas.

Kata Kunci-puskesmas, prediksi, least square, MMSL, MAPE.

\section{PENDAHULUAN}

Puskesmas merupakan pusat pelayanan kesehatan ditingkat pertama pada masyarakat. Puskesmas tidak hanya berfungsi sebagai pelayanan publik, tetapi juga berfungsi sebagai pelayanan klinis. Sehingga, kualitas pelayanan kesehatan terhadap masyarakat harus sesuai dengan standard pelayanan minimal di puskesmas. Kualitas ini dapat berupa kualitas sumber daya manusia, kualitas cara kerja, proses, dan pelayanan jasa [1], [2]. Pelayanan kesehatan yang diberikan kepada pasien, berbanding lurus terhadap nilai tingkat kepuasan masyarakat. Semakin baik pelayanan kesehatan, maka akan memberikan dampak kepuasan masyarakat yang semakin puas, dan juga sebaliknya [3], [4]. Pada penelitian akan membahas tentang ketersediaan obat bagi pasien dalam jumlah yang optimal.

Persediaan barang merupakan salah satu hal yang terpenting dalam sebuah perusahaan. persediaan barang ini berfungsi untuk antisipasi terhadap ketersediaan barang habis [5]. Pentingnya terhadap ketersediaan Obat, membuat puskesmas harus selalu memonitor pengunaan obat, dan merencanakan penggunaan obat. Kegiatan pemantauan dan perencanaan obat tertuang dalam Laporan Pemakaian dan Lembar Permintaan Obat (LPLPO) yang ditujukan ke Dinas Kesehatan terkait oleh puskesmas.

Puskesmas harus menyediakan persediaan obat untuk pasien selama jangka waktu 1 periode atau 1 bulan. Serta, puskesmas juga harus membuat perencanaan permintaan obat 
selama satu periode di bulan berikutnya.Apabila permintaan obat terlalu banyak akan mengakibatkan obat akan tertumpuk dalam jangka waktu yang lama, sehingga akan mengakibatkan kadaluarsa obat. Begitupula, apabila permintaan obat terlalu sedikit maka menjadi kurang baik, yang mengakibatkan pelayanan kepada masyarakat kurang optimal [6]. Selama ini, perencanaan permintaan obat untuk penggunaan di periode selanjutnya, masih menggunakan teknik insting oleh kepala gudang obat puskesmas. Sehingga, hal ini akan mengakibatkan kelebihan atau bahkan bisa berkurangnya persediaan obat. Sehingga, permasalahan ini dapat diselesaikan dengan cara memprediksi kebutuhan obat dimasa periode mendatang untuk kebutuhan obat bagi pasien. Selain itu juga, dibutuhkan sistem yang mampu mengontrol ambang batas atas dan ambang batas bawah persediaan obat dengan baik.

Pada penelitian ini akan membangun sebuah sistem yang mampu memprediksi kebutuhan obat di masa mendatang. Hasil prediksi ini dapat dijadikan sebagai acuan dalam perencanaan permintaan obat ke dinas kesehatan. Tujuan dilakukannya penelitian ini yaitu mampu membangun sistem prediksi kebutuhan persediaan obat di puskesmas dimasa mendatang dengan menggunakan metode Least Square. Sehingga, sistem ini dapat membantu proses perencanaan kebutuhan obat dimasa mendatang di puskesmas.

\section{PENELITIAN YANG TERKAIT}

Penelitian lain yang berkaitan yaitu tentang pengendalian persediaan obat generik telah banyak dilakukan diantaranya pada [7], [8]. Sistem tersebut bertujuan untuk menganalisis kebutuhan obat dimasa mendatang menggunakan metode least square. Data pengujiannya diperoleh dari unit farmasi pada Rumah Sakit Islam Surabaya [7] dan Rumah Sakit Bhayangkara [8]. Penelitian tentang sistem peramalan stok obat juga dilakukan menggunakaan metode exponential smoothing [6]. Prediksi terhadap kebutuhan obat juga dilakukan menggunakan metode regresi linier [9]. Selain untuk peramalan kebutuhan obat dimasa mendatang, metode Least Square juga dimanfaatkan untuk membangun sistem prediksi pengembalian stok pada industri farmasi [10].

Pada penelitian ini, merancang dan membangun sistem prediksi terhadap kebutuhan obat yang diperlukan oleh puskesmas dalam satu periode atau satu bulan. Bentuk visualisasi hasil prediksi ditampilkan melalui web, serta tempat pengambilan data dilakukan secara langsung. Implementasi dalam penelitian ini dilaksanakan di puskesmas. Metode perancangan sistem menggunakan metode waterfall dan dibangun berbasis web. Kemudian dilakukan pengujian terhadap hasil prediksi menggunkaan metode MAPE, yang hasilnya akan ditampilkan dalam bentuk laporan. Metode yang digunakan untuk memprediksi adalah Metode Least Square. Sedangkan untuk pengendalian persediaan untuk obat, yang meliputi batas bawah dan batas atas terhadap persedian obat menggunakan metode minimummaximum stock level.

\section{METODE PENELITIAN}

Metode penelitian ini terbagi menjadi dua bagian, yaitu bagian bahan dan alat penelitian, serta kerangka penelitian. Berikut adalah detail dari masing-masing bagian.

\section{A. Bahan dan Alat Penelitian}

Bahan dan alat penelitian merupakan sarana pendukung dalam penelitian Sistem Prediksi Kebutuhan Obat di Puskesmas Menggunakan Metode Least Square.

\section{1) Bahan Penelitian}

Tempat studi kasus penelitian ini di Puskesmas Singojuruh Kabupaten Banyuwangi. Puskesmas tersebut sudah mengimplementasikan aplikasi Sistem Informasi Puskesmas Banyuwangi (Simpuswangi) dalam hal pelayanan. Aplikasi ini juga sudah mengakomodir pengunaan obat, sehingga jumlah obat yang digunakan dalam satu periode terekam dengan baik. Persediaan obat berada digudang obat puskesmas, kemudian obat ini didistribusikan ke masyarakat melalui apotik puskesmas atau pihak lain dibawah puskesmas tersebut. Kepala gudang merupakan pihak yang berwenang untuk mengelola obat di gudang obat.

Pada penelitian ini menggunakan 13 nama obat dengan pemakaian terbesar sebagai sampel percobaan. Data ini diperoleh dari puskesmas pada tahun 2018. Tabel I merupakan daftar obat yang digunakan sebagai sampel percobaan.

TABEL I

DATA NAMA OBAT

\begin{tabular}{|c|l|c|l|}
\hline No & \multicolumn{1}{|c|}{ Nama Obat } & No & \multicolumn{1}{|c|}{ Nama Obat } \\
\hline 1 & Paracetamol tablet & 8 & Kalsium Laktat \\
\hline 2 & Asam Askorbat & 9 & Kofeniramine maleat \\
\hline 3 & Acyclovir 400Mg & 10 & Kaotrimaksasol \\
\hline 4 & Amocilin kapsul & 11 & Ranitidin \\
\hline 5 & $\begin{array}{l}\text { Anatasida Doen } \\
\text { kapsul }\end{array}$ & 12 & $\begin{array}{l}\text { Tablet Tambah } \\
\text { Darah }\end{array}$ \\
\hline 6 & Catropil & 13 & Vit B Thiamin \\
\hline 7 & Gliseril Guajakolat & - & \multicolumn{2}{|c|}{} \\
\hline
\end{tabular}

\section{2) Alat Penelitian}

Penelitian ini menggunakan beberapa alat perangkat lunak di antaranya adalah sebagai berikut:

- Bahasa pemrograman PHP,

- database MySQL,

- frameworkCodeIgniter

- editor Sublim text.

- Apache sebagaiweb server lokal

- Linux sebagai Sistem operasi

Perangkat keras yang digunakan adalah laptop dengan prosesor intel corei3 $1.4 \mathrm{GHz}$, dengan RAM 4 GB dengan kapasitas Hardisk 500GB dan video graphic on board.

\section{B. Kerangka Penelitian}

Pada penelitian ini menggunakan data histori obat yang merupakan data time series sehingga rekaman data masa lalu dijadikan pola untuk memprediksi kebutuhan obat dimasa mendatang.

Langkah-langkah dalam membangun sistem ini diantaranya yaitu, pertama-tama mengumpulkan data obat dari puskesmas. Kemudian, membangun aplikasi prediksi persediaan obat dengan menggunakan metode Least Square. Dilanjutkan dengan menguji-coba hasil metode tesebut menggunakan Mean Absolute Percentage Error (MAPE). Setelah hasilnya dinyatakan baik, maka dilanjutkan membangun sistem untuk memonitor pemakaian obat. Hal ini 
digunakan untuk menjaga tingkat persediaan batas bawah dan batas atas. Langkah terakhir yaitu mengintegrasikan kedalam tampilan pengguna berbasis web.

Kerangka penelitian sistem prediksi kebutuhan obat di puskesmas menggunakan metode least square dapat dilihat pada Gbr. 1 .

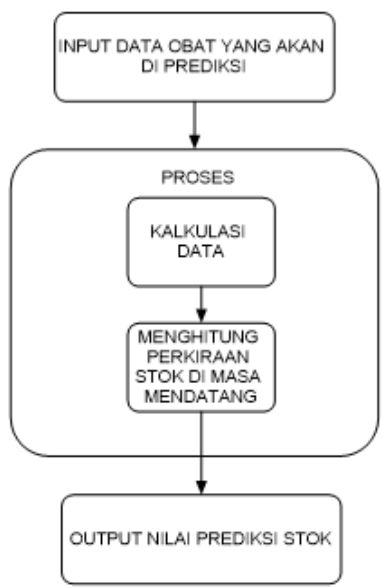

Gbr.1 Kerangka Penelitian Sistem Prediksi Kebutuhan Obat di Puskesmas

Metode yang digunakan untuk prediksi kebutuhan obat pada periode dimasa mendatang dapat dijelaskan sebagai berikut.

\section{1) Akuisisi Data}

Data obat diperoleh dari Puskesmas Singojuruh Kabupaten Banyuwangi. Data pemakaian ini diperoleh dari aktifitas pemakaian atau permintaan dari pasien dalam rentang waktu Januari 2018 sampai Desember 2018.

\section{2) Least Square.}

Proses prediksi dengan metode metode least square dapat dijelaskan melalui sebagai berikut [11]:

1. Menginisialisasi data masukan

2. Menentukan periode data/ variabel waktu

3. Menghitung jumlah pemakaian (Y),

4. Menghitung skor t.

5. Mencari nilai koefisien a menggunakan (1).

$$
a=\frac{\sum Y}{n}
$$

6. Menghitung nilai koefisien $\mathrm{b}$ terhadap $x$ (waktu) menggunakan (2)

$$
b=\frac{\sum t . Y}{t^{2}}
$$

7. Menentukan persamaan variabel nilai tren dengan (3)

$$
Y^{\prime}=a+b x
$$

\section{3) Metode Minimum Maximum Stock Level}

Safety stock adalah salah satu pendorong utama inventaris. Hal ini untuk melindungi terhadap peningkatan benturan di titik putus rantai pasokan, yang kemungkinan dapat pengurangan inventaris [12].

Terdapat tiga kategori Safety stock yaitu batas maksimum, batas minimum, dan kondisi safety. Kategori masing-masing obat akan berbeda-beda. Ketika persediaan obat berada pada posisi minimal, maka akan menampilkan indikator batas minimal obat [7].

Penentuan batas maksimal dan minimal persediaan obat menggunakan metode Minimum-Maximum Stock Level (MMSL). Metode ini berfungsi untuk pengendalian persediaan opname obat, agar supaya tidak terjadi kelebihan atau kekurangan persediaan [13].

Berikut adalah tahapan untuk menentukan MinimumMaximum Stock Level:

a) Menentukan persediaan pengaman (safety stock) menggunakan (4).

$$
R=(\text { Pemakaian maksimum }-T) \times \frac{c}{30}
$$

dimana:

$$
\begin{aligned}
& R=\text { safety stock } \\
& T=\text { pemakaian barang rata-rata per periode } \\
& C=\text { waktu tunggu pesanan (lead time) }
\end{aligned}
$$

b) Menentukan persediaan minimum dengan (5)

$$
\text { MinStock }=\left(T \times \frac{c}{30}\right) R
$$

dimana:

$$
\text { MinStock }=\text { persediaan minimum }
$$

c) Menentukan persediaan maksimum dengan (6)

$$
\text { MaxStock }=2\left(\frac{T \times c}{30}\right)
$$

dimana:

$$
\text { MaxStock }=\text { persediaan maksimum }
$$

\section{4) Pengujian Sistem}

Pengujian sistem digunakan untuk pengukuran kesalahan terhadap hasil prediksi dengan hasil aktual. Hasil dari perhitungan ini berupa presentase penyimpangan (error). Pengujian ketepatan prediksi persediaan obat pada penelitian ini menggunakan metode Mean Absolute Percentage Error [8]. Perhitungan MAPE menggunakan (7).

$$
M A P E=\frac{1}{n} \sum_{i=1}^{n} \frac{Y t-Y \prime t}{Y t} \times 100 \%
$$

dimana:

$$
\begin{array}{ll}
n & : \text { Jumlah data } \\
Y^{\prime} t & : \text { nilai prediksi pada periode ke- } i \\
Y t & : \text { data aktual pada periode ke- } i
\end{array}
$$

5) Metode pengembangan sistem tampilan pengguna

Pada tahapan pengembangan sistemprediksikebutuhanobat yaitu menggunakan metode waterfall, dimana proses dilakukan secara sekuensial atau urut dimulai dari analisa kebutuhan sistem, desain sitem, implementasi sistem, pengujian, dan maintenance [14]. Sistem ini diimplementasikan menggunakan bahasa PHP dan divisualisasikan berbasis web. 


\section{HASIL DAN PEMBAHASAN}

\section{A. Perancangan Sistem}

Model usecase diagram [15] pada perancangan sistem prediksi kebutuhan obat di puskesmas berbasis web dapat dilihat pada Gbr.2.

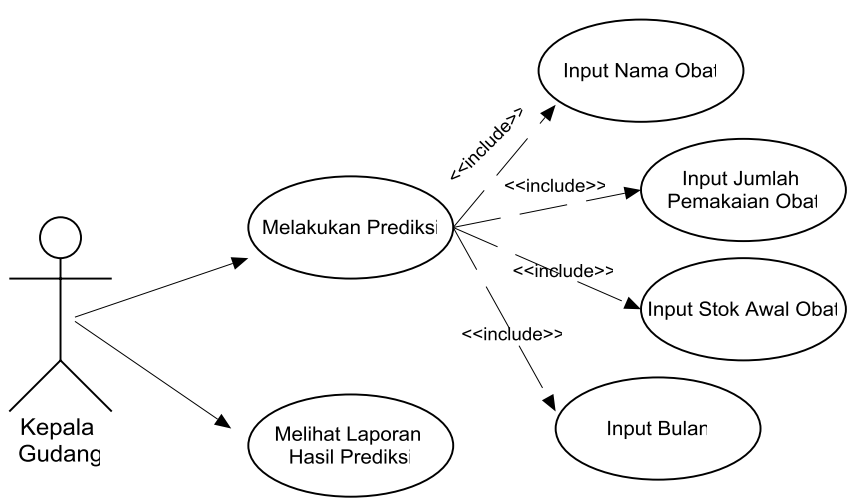

Gbr. 2 Perancangan Usecase Diagram

Perancangan Usecase Diagram seperti yang terlihat pada Gbr.2. Memiliki hanya satu aktor, yaitu Kepala Gudang farmasi di puskesmas. Usecase tersebut terbagi menjadi dua bagian, yaitu bagian melakukan prediksi dan bagian melihat laporan hasil prediksi. Sedangkan sistem melakukan prediksi terbagi beberapa sistem yaitu input nama obat, input jumlah pemakaian obat, inputpersediaan awal obat, dan input bulan.

\section{B. Implementasi Sistem}

Sistem dirancang menggunakan bahasa pemrograman PHP, database MySQL, framework CodeIgniter, serta editor Sublim text. Sedangkan, pengujian sistem menggunakan localhost. Sistem prediksi kebutuhan obat ini memiliki beberapa menu, diantaranya yaitu: menu beranda, menu data persediaan obat, menu kelola data obat, menu tambah obat, menu sistem prediksi obat, menu hasil prediksi, dan Menu SafetyStock. Menu meranda berisi tentang visi misi, motto dan grafik pemakaian obat yang ada di puskesmas. Hasil tampilan menu beranda ini seperti yang terlihat pada Gbr. 3 berikut.

Pada Gbr.4 merupakan tampilan dari data persediaan obat. Pada halaman ini berisi tetang persediaan awal obat, pemakaian obat dan sisa persediaan obat dari semua nama obat yang telah di inputkan oleh kepala gudang puskesmas. Menu data persediaan obat terdiri dari: Nama Obat, Bulan, Tahun, Persediaan awal, Pemakaian obat, dan Sisa persediaan. Pada menu kelola data obat seperti pada Gbr.5 diatas, berfungsi untuk menampilkan nama-nama obat yang ada di gudang framasi puskesmas. Kepala gudang farmasi puskesmas dapat melakukan penambahan nama obat,hapus nama obat, melihat data pemakaian pada setiap obat, penamhakan pemakaian ada setiap obat dan mengubah nama obat.

Sedangkan, menu tambah obat dapat dilihat seperti pada Gbr.6 berikut. Pada Menu ini digunakan untuk menambah kan data baru pada obat yang dipilih. Data yang di masukkan berupa data bulan dan data jumlah obat.

Pada Gbr. 7 merupakan menu sistem prediksi. Cara kerja proses prediksi ini yaitu, memilih nama obat yang akan diprediksi jumlah pemakaiannya di masa mendatang, kemudian ditandai dengan tanda centang pada nama-nama obat, selanjutnya tekan tombol proses untuk melanjutkan proses prediksi. Sedangkan, hasil dari prediksi pemakaian obat dimasa mendatang dapat dilihat pada Gbr. 8.
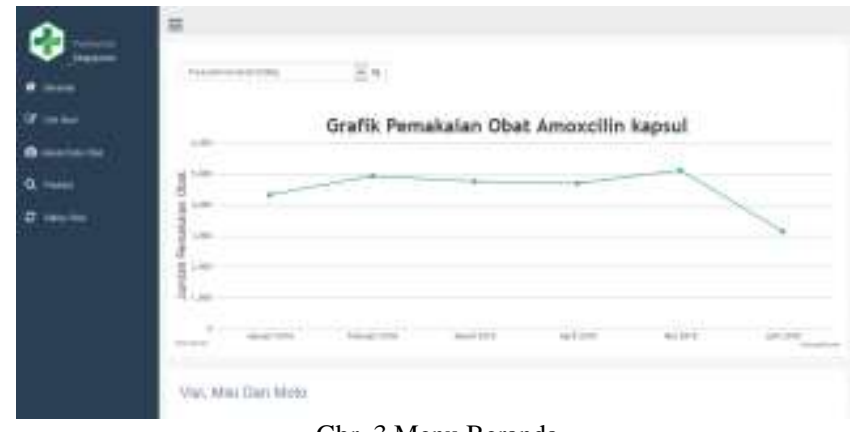

Gbr. 3 Menu Beranda

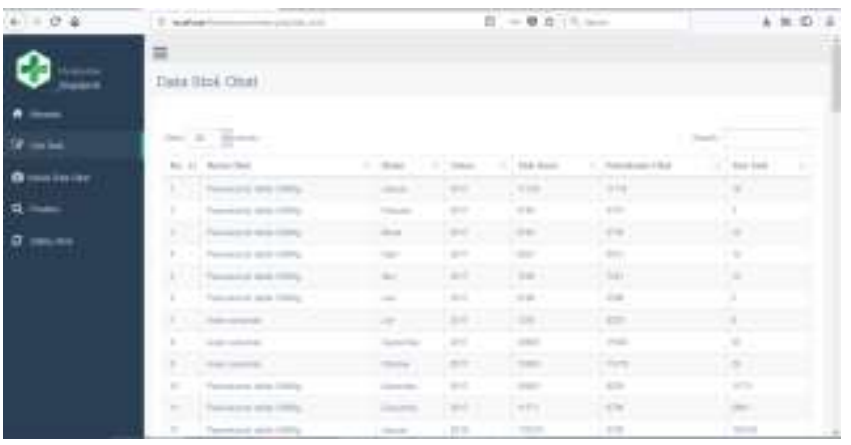

Gbr. 4 Menu Data Persediaan Obat
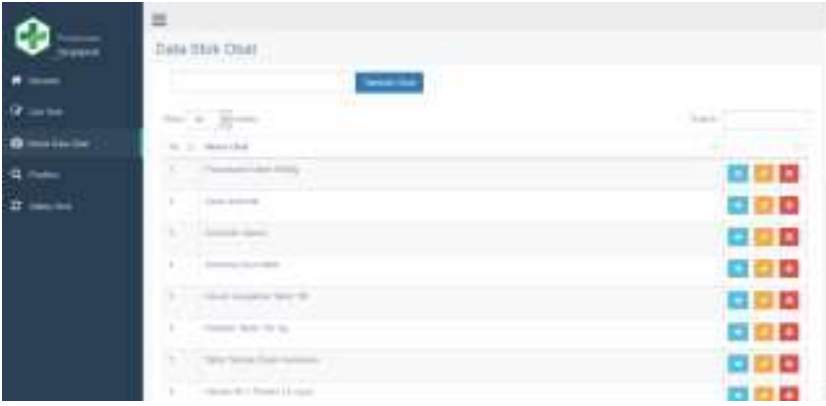

Gbr. 5 Menu Kelola Data Obat

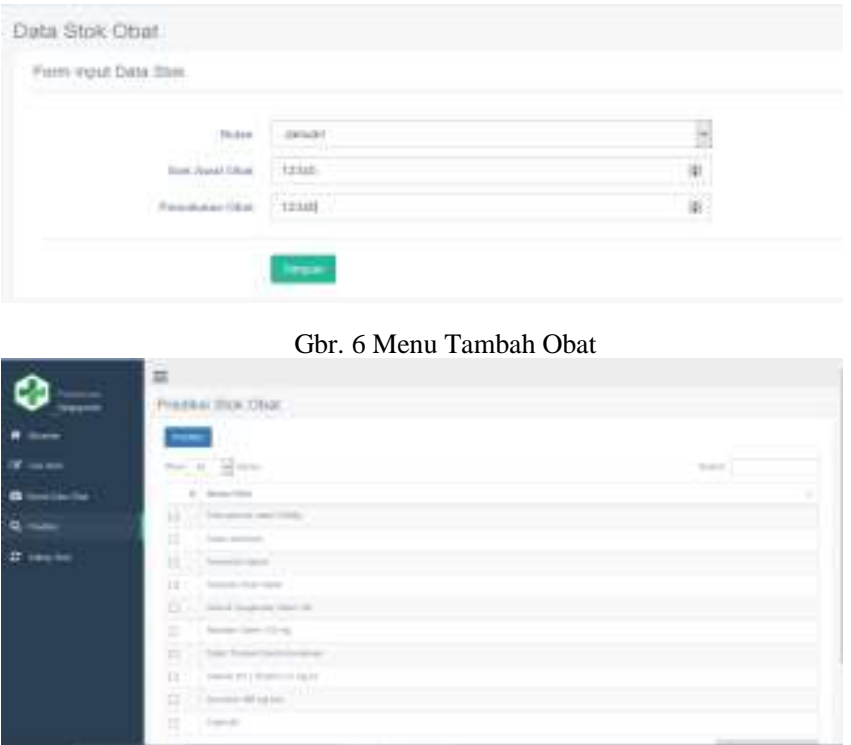

Gbr. 7 Menu Sistem Prediksi Obat 

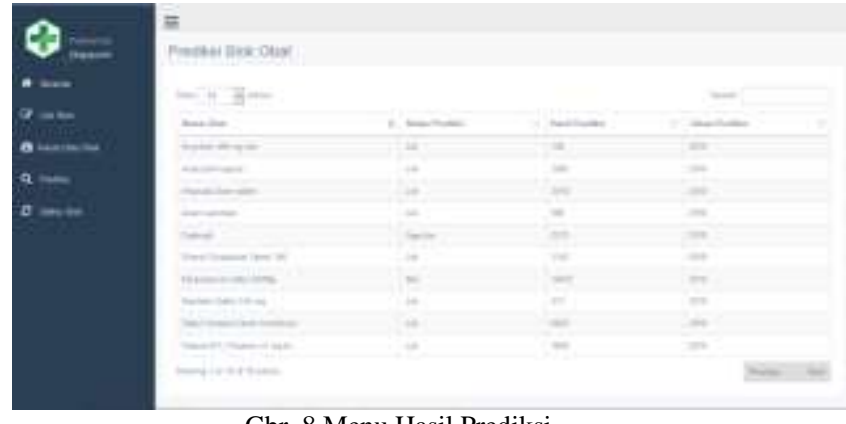

Gbr. 8 Menu Hasil Prediksi
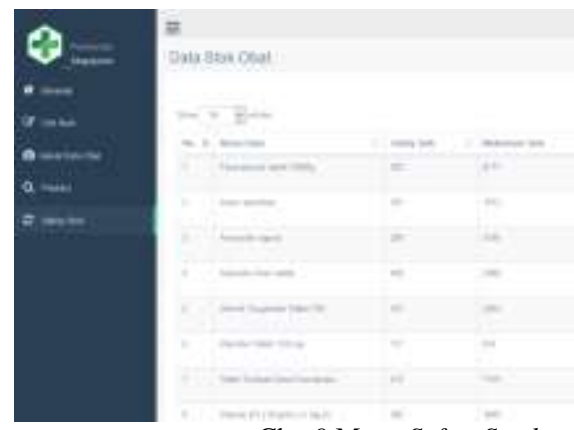

Gbr. 9 Menu Safety Stock

Pada Gbr.9 terdapat menu safety stock. Menu ini berfungsi untuk memantau kondisi jumlah persediaan obat.

\section{Pengujian Sistem}

Pengujian sistem prediksi ini menggunakan data pemakaian obat di Puskesmas Singojuruh Kabupaten Banyuwangi. Sistem prediksi ini menggunakan data time series. Data yang digunakan terdiri dari 13 nama obat. Sedangkan, data yang digunakan dalam pengujian sistem prediksi adalah data yang terkumpul selama 7 (tujuh) bulan.

Skenario pengujian ini yaitu, data yang terkumpul dibagi menjadi dua bagian, yaitu data training dan data testing. Data training adalah data pemakaian obat yang terakumulasi dalam satuan bulan. Parameter bulan diwakili dengan satuan $t$. Sedangkan, hasil prediksi pemakaian obat dimasa mendatang, yaitu ditandai dengan parameter bulan mendatang $t+1$. Data training dan data testing dapat dilihat pada Tabel II.
Pada Tabel II terlihat hasil prediksi dan data aktual. Hasil prediksi yang paling baik adalah pada nama obat Catropil, yaitu dengan nilai kesalahan prediksi sebesar $0.74 \%$. hal ini menunjukkan bahwa hasil prediksi mempunyai hasil kesamaan dengan data kebutuhan obat aktual. Hal ini berbeda dengan hasil prediksi nama obat Ranitidin. Nama obat ini mempunyai nilai kesalahan prediksi sebesar $30.15 \%$. Hasil prediksi yang kurang tepat, maka akan berdampak pada jumlah permintaan obat dimasa mendatang yang berlebihan atau kekurangan. Sedangkan rata-rata kesalahan dalam prediksi kebutuhan obat dimasa mendatang adalah sebesar $12.70 \%$

Hasil perbandingan antara data kebutuhan obat dimasa mendatang atau biasa disebut dengan data prediksi dengan data sebenarnya atau disebut dengan data aktual, dapat dilihat pada Gbr. 10

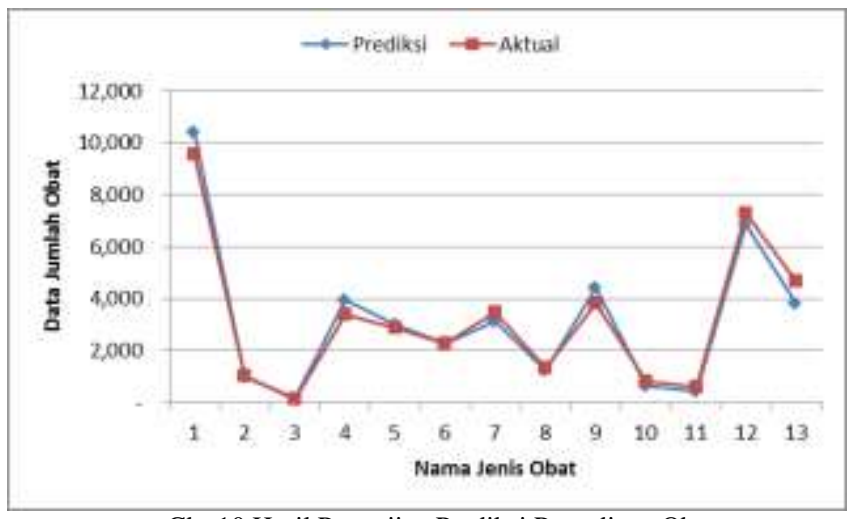

Gbr.10 Hasil Pengujian Prediksi Persediaan Obat

Pada Gbr.10 terlihat bahwa nama obat yang pertama yaitu Paracetamol tablet mempunyai tingkat kebutuhan yang tinggi yaitu sebesar 9560, hal ini sesuai dengan hasil prediksi yang dilakukan. Hasil prediksi menunjukkan bahwa kebutuhan obat Paracetamol tablet dimasa mendatang termasuk tinggi, yaitu 10427. Sehingga, dapat diperkirakan kesalahan dalam prediksi kebutuhan obat dimasa mendatang dengan menggunakan metode least square adalah $9.07 \%$.

TABEL II

HASIL PENGJIAN SISTEM PREDIKSI OBAT BERDASARKAN TIME SERIES

\begin{tabular}{|c|c|c|c|c|c|c|c|c|c|c|}
\hline \multirow{2}{*}{ No. } & \multirow{2}{*}{ Nama obat } & \multicolumn{6}{|c|}{ Data Training } & \multicolumn{2}{|c|}{ Data Testing } & \multirow{2}{*}{ Error \% } \\
\hline & & $\mathrm{t}-5$ & $\mathrm{t}-4$ & $\mathrm{t}-3$ & $\mathrm{t}-2$ & $\mathrm{t}-1$ & $\mathrm{t}$ & Prediksi & Aktual & \\
\hline 1 & Paracetamol tablet & 8229 & 8790 & 9700 & 9757 & 9750 & 9815 & 10427 & 9560 & $9.07 \%$ \\
\hline 2 & Asam Askorbat & 2567 & 2397 & 1479 & 1441 & 1170 & 1702 & 988 & 1021 & $3.23 \%$ \\
\hline 3 & Acyclovir 400Mg & 409 & 236 & 370 & 251 & 187 & 218 & 156 & 126 & $23.81 \%$ \\
\hline 4 & Amocilin kapsul & 4327 & 4937 & 4748 & 4690 & 5115 & 3153 & 3956 & 3375 & $17.21 \%$ \\
\hline 5 & Anatasida Doen kapsul & 3098 & 2639 & 3345 & 3986 & 3176 & 3172 & 3018 & 2856 & $5.67 \%$ \\
\hline 6 & Catropil & 1899 & 2082 & 1892 & 1997 & 1702 & 613 & 2273 & 2290 & $0.74 \%$ \\
\hline 7 & Gliseril Guajakolat & 4538 & 5076 & 4918 & 4642 & 3487 & 3207 & 3142 & 3470 & $9.45 \%$ \\
\hline 8 & Kalsium Laktat & 232 & 1194 & 1368 & 688 & 1273 & 1038 & 1258 & 1342 & $6.26 \%$ \\
\hline 9 & Kofeniramine maleat & 3360 & 3800 & 4570 & 3980 & 3846 & 4317 & 4412 & 3817 & $15.59 \%$ \\
\hline 10 & Kaotrimaksasol & 1437 & 973 & 892 & 935 & 726 & 945 & 669 & 832 & $19.59 \%$ \\
\hline 11 & Ranitidin & 756 & 665 & 908 & 667 & 567 & 382 & 417 & 597 & $30.15 \%$ \\
\hline 12 & Tablet Tambah Darah & 7660 & 8560 & 8460 & 7028 & 7136 & 7178 & 6856 & 7274 & $5.75 \%$ \\
\hline 13 & Vit B Thiamin & 4897 & 3987 & 3735 & 3523 & 4507 & 4038 & 3820 & 4690 & $18.55 \%$ \\
\hline \multicolumn{10}{|c|}{ rata-rata error } & $12.70 \%$ \\
\hline
\end{tabular}




\section{KESIMPULAN}

Sistem Prediksi kebutuhan obat pada masa mendatang di Puskesmas menggunakan metode Least Square dapat disimpulkan bahwa aplikasi sistem prediksi kebutuhan obat di puskesmas mampu melakukan proses prediksi kebutuhan obat dimasa mendatang berdasarkan kriteria yang telah ditentukan, dan mampu menghasilkan hasil laporan data obat yang dibutuhkan. Tingkat kesalahan dalam prediksi kebutuhan obat yang terendah sebesar $0,74 \%$ yaitu pada obat catropil, sedangkan kesalahan terbesar pada obat Ranitidin, yaitu sebesar $30,15 \%$. Sedangkan tingkat error rata-rata adalah $12,70 \%$.

Saran yang dapat diberikan dalam penelitian ini yaitu 1) perlu adanya data yang besar dengan harapan mempunyai akurasi prediksi yang tinggi; 2) Perlu melibatkan paramater yang lain seperti parameter musim iklim, atau musim bulan; 3) Serta perlu dikembangkan yang dapat diintegrasikan dengan sistem informasi puskesmas, apotik, dan gudang farmasi.

\section{UCAPAN TERIMA KASIH}

Terima kasih penulis kepada Pusat Penelitian dan Pengabdian Masyarakat (P3M) Politeknik Negeri Banyuwangi yang telah mendanai kegiatan penelitian ini melalui skema Penelitian Berbasis Rencana Induk Penelitian (RIP).

\section{DAFTAR PUSTAKA}

[1] E. Sugiarto, Psikologi Pelayanan dalam Industri Jasa. Jakarta: Gramedia Pustaka Utama, 2003.

[2] W. Utami and A. A. Bachri, "Pengaruh Dimensi Kualitas Pelayanan Puskesmas S . Parman Banjarmasin Terhadap Kepuasan Pasien Dalam Memperoleh Pelayanan Kesehatan," J. Wawasan Manaj., vol. 1, no. 1, pp. 65-90, 2013.
[3] O. D. Pertiwi and I. Khasanah, "Analisis Pengaruh Kualitas Pelayanan Terhadap Kepuasan Konsumen (Studi Pada Pasien Poli Spesialis Rumah Sakit St. Elisabeth Semarang)," Anal. Pengaruh Kualitas Pelayanan Terhadap Kepuasaan Konsum., vol. 2010, no. 2, pp. 117 124, 2010.

[4] K. J. Rosalia and N. K. Purnawati, "Pengaruh Kualitas Pelayanan Terhadap Kepuasan Pasien RSU Surya Husadha di Denpasar," EJurnal Manaj. Unud, vol. 7, no. 5, pp. 2442-2469, 2018.

[5] C. Mekel, S. P. Anantadjaya, and Lahindah, "Stock Out Analysis: An Empirical Study on Forecasting, Re-Order Point and Safety Stock Level at PT Combiphar, Indonesia," Rev. Integr. Bus. Econ. Res., 2014.

[6] E. Mala Sari R, Y. Kustiyahningsih, and R. Sugiharto, "Sistem Peramalan Stok Obat Menggunakan Metode Exponential Smoothing," in Konferensi Nasional Sistem \& Informatika 2015, 2015, pp. 216221.

[7] A. Kumalasari and T. N. Rochmah, "Pengendalian Persediaan Obat Generik Dengan Metode MMSL (Minimum-Maximum Stock Level) di Unit Farmasi Rumah Sakit Islam Surabaya," J. Manaj. Kesehat. STIKES Yayasan RS dr. Soetomo, vol. 2, no. 2, pp. 143-152, 2016.

[8] M. Rahmawita and I. Fazri, "Aplikasi Peramalan Penjualan Obat Menggunakan Metode Least Square di Rumah Sakit Bhayangkara," $J$. Ilm. Rekayasa dan Manaj. Sist. Inf., vol. 4, no. 2, pp. 201-208, 2018.

[9] P. Sulardi, T. Hendro, and F. R. Umbara, "Prediksi Kebutuhan Obat Menggunakan Regresi Linier,” Snatif, pp. 57-62, 2017.

[10] A. Kebriaee-Zadeh, S. Zartab, S. F. Fatemi, and R. Radmanesh, "Fundamentals and stock return in pharmaceutical companies: A panel data model of Iranian industry," Iran. J. Pharm. Sci., 2014.

[11] N. Ekawati, "Prediction of Poor Inhabitant Number Using Least Square and Moving Average Method," TELKOMNIKA, vol. 16, no. 2, pp. 369-376, 2015.

[12] B. Amirjabbari and N. Bhuiyan, "Determining supply chain safety stock level and location," J. Ind. Eng. Manag., 2014.

[13] R. E. Nugroho, D. Albar, and S. Hasibuan, "Improved Inventory Management Performance in Indonesia Spare-Parts Company Using ABC Classification and Min-Max Method," Saudi J. Bus. Manag. Stud., vol. 3, no. 3, pp. 248-252, 2018.

[14] R. S. Pressman, Software Engineering: A Practitioner's Approach, 7th ed. New York: McGraw-Hill, 2010.

[15] R. A. Sukamto and M. Shalahuddin, Rekayasa Perangkat Lunak. Bandung: Informatika, 2014. 